Goldschmidt 2021 Abstract

https://doi.org/10.7185/gold2021.3698

\section{in-situ phosphatization of fish scales: the possible role of bacterial alcaline phosphatase in fossilization}

\author{
FABIAN M GÄB ${ }^{1}$, CHRISTOPH BULTMANN ${ }^{2}$ AND \\ KATHRIN JANSSEN ${ }^{3}$
}

${ }^{1}$ Universität Bonn

${ }^{2}$ Sana Klinikum Offenbach

${ }^{3}$ University Hospital Bonn

Presenting Author: fgaeb@uni-bonn.de

Phosphatized fish fossils occur in various locations on the world, including the Santana Formation in Brazil, the Gogo formation in Australia, and the Solnhofen deposits in Germany. Although these fossils have been studied intensively over the past decades, the mechanism of the permineralization reaction itself remains poorly understood. The mineralization of a fish requires a substantial amount of phosphate, which has not been available in seawater. The source of the phosphate and the chemical pathway of mobilizing large amounts of phosphate remain unclear.

In 2015 J. Cosmidis published an article on the possible role of bacterial alkaline phosphatase (AP) on this problem [1]. She showed that AP is able to increase the phosphate content in a medium surrounding E. Coli bacteria, and that this increase would eventually lead to the precipitation of hydroxy-apatite. We applied this study to an experimental setup where fish rays with attached fin tissue were exposed to commercial bovine alcaline phosphatase in natural seawater for several days. We analyzed the samples by SEM and EDX and detected $\sim 3 \mu \mathrm{m}$ apatite crystals on the remaining soft tissue. A control experiment without added AP did not produce any apatite. The AP did extract phosphate from organic tissue, which then formed apatite. To strengthen the hypothesis, the experiment was redone with fish scales, commercial bovine AP, and NPP (a substance that is used as AP substrate). These experiments were also left to react for several days and were analyzed by SEM and EDX. The fish scales were completely coated by a layer of apatite (Fig. 1). The apatite traced the biological structures of the scales (growth rings) and was precipitated in small spheres (Fig. 2), as reported before in literature. These results show, that bacterial AP might have played an important role in fish fossilization and indicate the need for further experimental work.

[1] Cosmidis, Benzerara, Guyot, Skouri-Panet, Duprat, Ferard, Guigner, Babonneau \& Coelho (2015). Frontiers in Earth Science 3, 84.
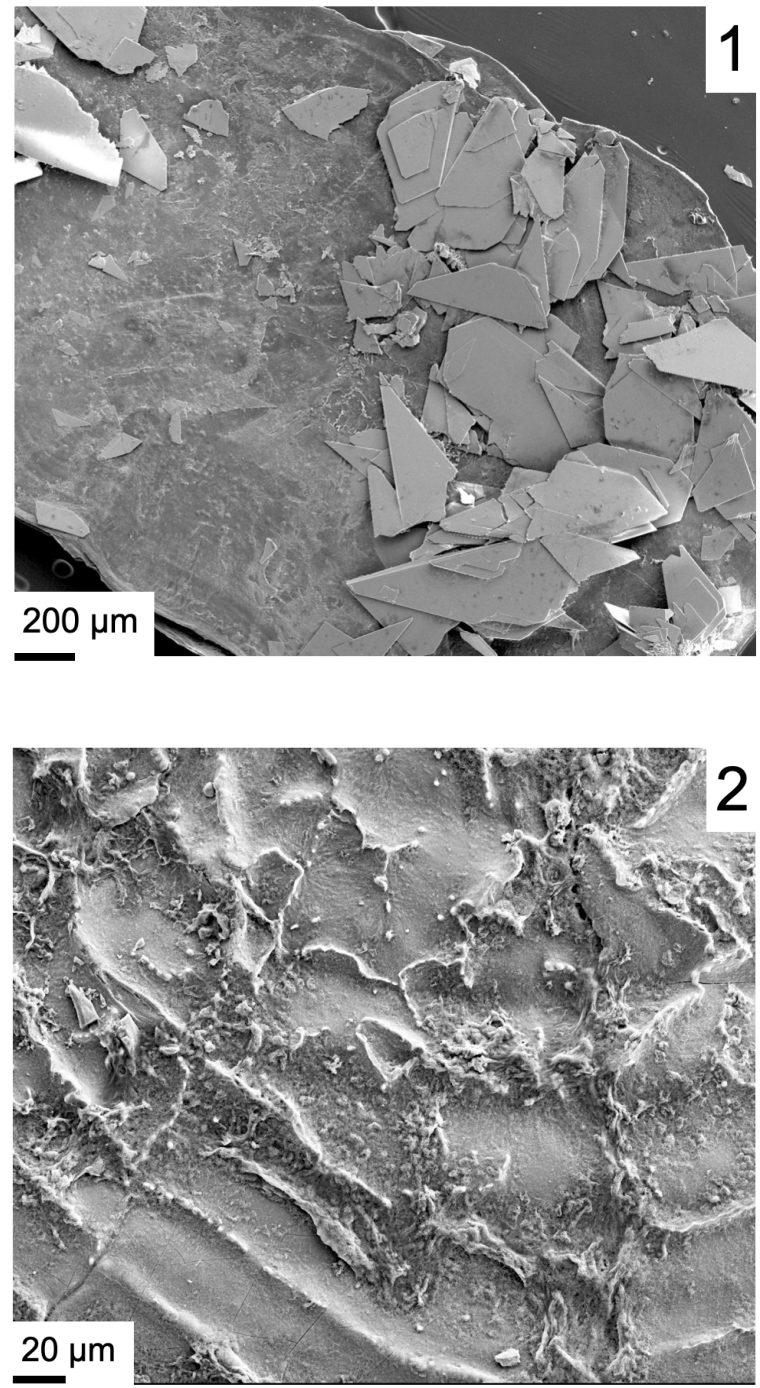